Article

\title{
Carpinus turczaninowii Extract May Alleviate High Glucose-Induced Arterial Damage and Inflammation
}

\author{
Juhyun Song ${ }^{1,+}$, So Ra Yoon ${ }^{2,3,4,+}$, Youn Kyoung Son ${ }^{5}$, Woo Young Bang ${ }^{5}{ }^{(\mathbb{D}}$, Chang-Hwan Bae ${ }^{5}$, \\ Joo-Hong Yeo ${ }^{5}$, Hyun-Jin Kim ${ }^{6}$ and Oh Yoen Kim ${ }^{2,3, *(1)}$ \\ 1 Department of Anatomy, Chonnam National University Medical School, Gwangju 61469, Korea; \\ juhyunsong@chonnam.ac.kr \\ 2 Department of Food Science and Nutrition, Dong-A University, 37550 beon-gil Nakdongdae-ro, Saha-gu, \\ Busan 49315, Korea; yunsora0917@naver.com \\ 3 Center for Silver-Targeted Biomaterials, Brain Busan 21 Plus Program, Dong-A University, 37 550beon-gil \\ Nakdongdae-ro, Saha-gu, Busan 49315, Korea \\ 4 Institute of Health Insurance and Clinical Research, National Health Insurance Service Ilsan Hospital, 100 \\ Ilsan-ro, Ilsandong-gu, Goyang-si, Gyeonggi-do 10444, Korea \\ 5 Biological Resources Utilization Department, National Institute of Biological Resources, 42 Hwangyeong-ro, \\ Seo-gu Incheon 22689, Korea; sophy004@korea.kr (Y.K.S.); wybang@korea.kr (W.Y.B.); \\ bae0072@korea.kr (C.-H.B.); y1208@korea.kr (J.-H.Y.) \\ 6 Department of Food Science \& Technology, and Institute of Agriculture and Life Science, Gyeongsang \\ National University, 501 Jinju-daero, Jinju 52828, Korea; hyunjkim@gnu.ac.kr \\ * Correspondence: oykim@dau.ac.kr; Tel.: +82-51-200-7326; Fax: +82-51-200-7353 \\ + These two authors contributed equally to the work as primary authors.
}

Received: 6 May 2019; Accepted: 7 June 2019; Published: 11 June 2019

\begin{abstract}
Hyperglycemia-induced oxidative stress triggers severe vascular damage and induces an inflammatory vascular state, and is, therefore, one of the main causes of atherosclerosis. Recently, interest in the natural compound Carpinus turczaninowii has increased because of its reported antioxidant and anti-inflammatory properties. We investigated whether a C. turczaninowii extract was capable of attenuating high glucose-induced inflammation and arterial damage using human aortic vascular smooth muscle cells (hASMCs). mRNA expression levels of proinflammatory response [interleukin-6 (IL-6), tumor necrosis factor- $\alpha$ (TNF- $\alpha$ )], endoplasmic reticulum (ER) stress [CCAAT-enhancer-binding proteins (C/EBP) homologous protein (CHOP)], and adenosine monophosphate (AMP)-protein activated kinase $\alpha 2$ (AMPK $\alpha 2$ )], and DNA damage [phosphorylated H2.AX (p-H2.AX)] were measured in hASMCs treated with the C. turczaninowii extracts (1 and $10 \mu \mathrm{g} / \mathrm{mL})$ after being stimulated by high glucose $(25 \mathrm{mM})$ or not. The $C$. turczaninowii extract attenuated the increased mRNA expression of IL-6, TNF- $\alpha$, and CHOP in hASMCs under high glucose conditions. The expression levels of $\mathrm{p}-\mathrm{H} 2 \mathrm{AX}$ and AMPK $\alpha 2$ induced by high glucose were also significantly decreased in response to treatment with the $C$. turczaninowii extract. In addition, 15 types of phenolic compounds including quercetin, myricitrin, and ellagic acid, which exhibit antioxidant and anti-inflammatory properties, were identified in the C. turczaninowii extract through ultra-performance liquid chromatography-quadrupole-time of flight (UPLC-Q-TOF) mass spectrometry. In conclusion, C. turczaninowii may alleviate high glucose-induced inflammation and arterial damage in hASMCs, and may have potential in the treatment of hyperglycemia-induced atherosclerosis.
\end{abstract}

Keywords: Carpinus turczaninowii; human aortic vascular smooth muscle cells; high glucose; inflammation; arterial damage; phenolic compounds 


\section{Introduction}

Diabetes mellitus (DM) has been known to cause cerebral vascular disorder and cardiovascular diseases (CVD), which are the major causes of death in patients with DM [1,2]. Several studies reported that the morbidity and mortality of DM patients are the result of vascular dysfunction [3-5]. DM patients had a four-fold higher risk for CVD compared to normal healthy subjects [6], and also showed elevated oxidative stress due to increased glucose oxidation, impaired redox cycle, enhanced glycation, and enhanced polyol pathway activity [7]. The increased oxidative stress in DM patients accelerates the progression of atherosclerosis and aggravates various cardiovascular events by promoting inflammation, blood plaque instability, endothelial dysfunction, and proliferation and migration of vascular smooth muscle cells (VSMCs) [8]. Although many factors contribute to the progression of atherosclerosis in DM patients, oxidative stress induced by hyperglycemia has been implicated as a potential mechanism that accelerates atherosclerosis progression [9-11]. In DM patients, excessive circulating glucose induces oxidative stress and promotes the production of the free radical-yielding superoxide anion $\left(\mathrm{O}_{2}{ }^{-}\right)$and hydrogen peroxide $\left(\mathrm{H}_{2} \mathrm{O}_{2}\right)$ [12]. Hyperglycemia generates excessive reactive oxygen species (ROS), produced by the proton electromechanical gradient [9], resulting in severe diabetes-related vascular complications [3], DNA damage, and lipid peroxidation [13,14]. Several studies have shown that elevated glucose concentrations result in the impairment of an antioxidant defense in both diabetic animal models and DM patients [15]. The modulation of hyperglycemia may be a key to improve various diabetic pathologies and to prevent the progression of atherosclerosis by inhibiting vascular damage in DM patients.

Previous studies suggested that hyperglycemia in DM patients could be improved by natural antioxidant compounds such as reducers of glutathione, and vitamins E and C [16,17], which regulate oxidative stress and inflammatory processes [18,19]. Among the natural compounds, phytochemical compounds derived from plants have been considered important all over the world because of their roles in increasing antioxidant capacity, regulating enzyme activity, and modulating gene transcription $[19,20]$. Carpinus turczaninowii (C. turczaninowii), a member of the Betulaceae family, has been reported to play a role in antioxidant regulation and anti-inflammation modulation [21-27]. Carpinus turczaninowii (C. turczaninowii), a member of the Betulaceae family (Korean hornbeam) usually grown in the Jeju islands of Korea, has been reported to play a role in antioxidant regulation and anti-inflammation modulation [21-27]. Recent studies showed dose-dependent inhibition of nitric oxide (NO) and interleukin (IL)-6 productions from LPS-stimulated RAW264.7 cells ( $1 \mu \mathrm{g} / \mathrm{mL}$ of LPS) by the extract of C. turczaninowii branches and leaves (12.5 to $200 \mu \mathrm{g} / \mathrm{mL})$ [21-24]. Antibacterial properties and skin-whitening (murine melanoma cells) were also observed in the C. turczaninowii leaf extract [24]. In our recent study, a complete extract of $C$. turczaninowii was found to contain high amounts of total phenolic compounds $(225.6 \pm 21.0 \mathrm{mg}$ of gallic acid equivalents $/ \mathrm{g}$ of the extract), as well as strongly scavenged free radicals (average $14.8 \pm 1.97 \mu \mathrm{g} / \mathrm{mL} \mathrm{IC} \mathrm{I}_{50}$ at $40 \mathrm{~min}$ ) [27]. In addition, mRNA expressions of interleukin-6 (IL-6) and tumor necrosis factor (TNF)- $\alpha$ in human aortic vascular smooth muscle cells (hASMCs) were significantly suppressed by the extracts ( 1 and $10 \mu \mathrm{g} / \mathrm{mL}$ ) at $6 \mathrm{~h}$ after exposure, and IL-6 secretion was dose-dependently suppressed at $2 \mathrm{~h}$ and $24 \mathrm{~h}$ after incubation with the extract at $1-10 \mu \mathrm{g} / \mathrm{mL}$ in non-stimulated and LPS-stimulated cells [27]. Given that C. turczaninowii has antioxidant capacity, we hypothesized that it may protect arterial cells from the hyperglycemia-induced oxidative stress, but the mechanism is not fully understood. Thus, we investigated how the C. turczaninowii extract modulates arterial inflammatory response and damage under high glucose conditions using human aortic VSMCs (hASMCs).

\section{Materials and Methods}

\subsection{C. turczaninowii Extract Preparation}

C. turczaninowii (branches, leaves, and trunk) were exclusively collected from Suin Mountain (GangjinGun, Korea) in January 2015, and identified by a plant taxonomist and curator associated 
with the Natural History Museum of Hannam University (Daejeon, Korea, specimen deposition \#: NIBRVP0000519846). Briefly, the plant material was air-dried, ground, and extracted three times with $70 \%$ ethanol for $24 \mathrm{~h}$ at room temperature. The extract was filtered, evaporated under reduced pressure, freeze-dried to obtain a powder, and then stored in a deep freezer $\left(-80{ }^{\circ} \mathrm{C}\right)$ before testing. For the experiments, the lyophilized C. turczaninowii extract powder was dissolved in $70 \%$ ethanol and filtered (0.2 $\mu \mathrm{m}$ Minisart ${ }^{\circledR}$ syringe filter, Sartorius Stedim Biotech GmbH, Goettingen, Germany). The extract stock solution (final concentration: $30 \mathrm{mg} / \mathrm{mL}$ ) was then aliquoted and stored at $-80{ }^{\circ} \mathrm{C}$ for further analysis.

\subsection{Cell Culture and Treatment Condition}

Primary human aortic smooth muscle cells (hASMCs) (ATCC PCS-100-012, American Type Culture Collection, ATCC, Manassas, VA, USA) were maintained in a humidified atmosphere of $37^{\circ} \mathrm{C}$, with $5 \% \mathrm{CO}_{2}$ in VSMC basal medium (without glucose and phenol red) (ATCC ${ }^{\circledR}$ PCS-100-030 ${ }^{\mathrm{TM}}$ ) supplemented with recombinant human basic fibroblast growth factor $(5 \mathrm{ng} / \mathrm{mL})$, rhInsulin $(5 \mu \mathrm{g} / \mathrm{mL})$, recombinant human epidermal growth factor $(5 \mathrm{ng} / \mathrm{mL})$, L-glutamine $(10 \mathrm{mM})$, ascorbic acid $(50 \mu \mathrm{g} / \mathrm{mL})$, fetal bovine serum (5\%), gentamicin $(10 \mu \mathrm{g} / \mathrm{mL})$, penicillin $(10$ Units/mL), streptomycin $(10 \mu \mathrm{g} / \mathrm{mL})$, amphotericin B $(0.28 \mu \mathrm{g} / \mathrm{mL})$, and phenol red $(33 \mu \mathrm{M})$ (ATCC). To induce clinically hyperglycemic condition, we stimulated the cells with $25 \mathrm{mM}(450 \mathrm{mg} / \mathrm{dL})$ of glucose. Based on our previous study for cell viability [27], we used 1 and $10 \mu \mathrm{g} / \mathrm{mL}$ concentration of $C$. turczaninowii extract in this study.

\subsection{Quantitative Real Time-PCR}

To examine mRNA expression of interleukin (IL)-6, tumor necrosis factor- $\alpha$ (TNF- $\alpha$ ), CCAAT-enhancer-binding proteins (C/EBP) homologous protein (CHOP), and adenosine monophosphate (AMP)-protein activated kinase $\alpha 2$ (AMPK $\alpha 2$ ) in hASMCs, we performed quantitative real time-polymerase chain reaction (qPCR). hASMCs were treated with the extract (final concentration: 1 and $10 \mu \mathrm{g} / \mathrm{mL})$ under high glucose condition $(25 \mathrm{mM})$ or not, and then incubated for $6 \mathrm{~h}$. Briefly, total cellular RNA was extracted from hASMCs using TRIzol reagent (Invitrogen, Carlsbad, CA, USA) according to the manufacturer's protocol. Poly (A) was added using poly (A) polymerase (Ambion, Austin, TX, USA). One Step SYBR ${ }^{\circledR}$ Prime Script TM RT-PCR Kit II (Takara, Otsu, Shiga, Japan) was used to conduct the qPCR reaction. PCR was performed using the following primers $\left(5^{\prime}\right.$ to $\left.3^{\prime}\right)$ : TNF- $\alpha$ (F): CGT CAG CCG ATT TGC TAT CT, (R): CGG ACT CCG CAA AGT CTA AG; IL-6 (F): GTT GCC TTC TTG GGA CTG AT, (R): CTG GCT TTG TCT TTC TTG TTA T, CHOP: (F): AGA ACC AGG AAA CGG AAA CAG A (R): TCT CCT TCA TGC GCT GCT TT, AMPK $\alpha 2$ (F): GCT GTG GAT CGC CAA ATT AT, (R): GCA TCA GCA GAG TGG CAA TA, and $\beta$-actin (F): TCT GGC ACC ACA CCT TCT A, (R): AGG CAT ACA GGG ACA GCA C. The PCR was performed at $42^{\circ} \mathrm{C}$ for $5 \mathrm{~min}, 95^{\circ} \mathrm{C}$ for $10 \mathrm{~s}$, followed by 40 cycles of $95^{\circ} \mathrm{C}$ for $15 \mathrm{~s}, 60^{\circ} \mathrm{C}$ for $34 \mathrm{~s}$, and $65^{\circ} \mathrm{C}$ for $15 \mathrm{~s}$. The mRNA expression of each transcript was assessed on an ABI prism 7500 Real-Time PCR System (Life Technologies Corporation, Carlsbad, CA, USA) and analyzed with comparative Ct quantification. $\beta$-actin was amplified as an internal control. The values were presented by relative quantity (RQ). Three wells were used in each condition per experiment, and all the experiments were repeated three times.

\subsection{Immunocytochemistry}

hASMCs treated with the extract under high glucose condition or not were washed three times with PBS and permeabilized for $20 \mathrm{~min}$. The cells were incubated with the primary antibodies for $16 \mathrm{~h}$ at $4{ }^{\circ} \mathrm{C}$. Anti-rabbit phosphorylated H2.AX (1:500, Cell Signaling, Danvers, MA, USA) was used as the primary antibody. After a $16 \mathrm{~h}$ incubation, hASMCs were washed three times with PBS and incubated with each specific secondary antibody for $1.5 \mathrm{~h}$ at room temperature. The cells were washed three times for 3 min with PBS and were counterstained with $1 \mu \mathrm{g} / \mathrm{mL} \mathrm{4}$, 6-diamidino-2-phenylindole (DAPI, 1:200, Invitrogen) for $10 \mathrm{~min}$ at room temperature. Cells were imaged using a Zeiss LSM 700 confocal microscope (Carl Zeiss, Thornwood, NY, USA). 


\subsection{UPLC-Q-TOF MS: Identification of Phenolic Compounds from C. turczaninowii Extract}

Phenolic compounds from $C$. turczaninowii were analyzed by an ultra-performance liquid chromatography-quadrupole-time of flight (UPLC-Q-TOF) mass spectrometry (MS) (Waters, Milford, MA, USA). The extract was injected into an Acquity UPLC BEH C18 column $(2.1 \mathrm{~mm} \times 100 \mathrm{~mm}, 1.7 \mathrm{um}$; Waters) at a column temperature of $40{ }^{\circ} \mathrm{C}$. Mobile phase consisted of water with formic acid (FA, $0.1 \%$ ) (A) and ACN with FA $(0.1 \%, \mathrm{~B})$ at a flow rate of $0.35 \mathrm{~mL} / \mathrm{min}$ for $9 \mathrm{~min}$. The eluents were ionized by electrospray ionization with negative mode and analyzed using a Q-TOF MS. The scan range of TOF MS data was from 50 to $1500 \mathrm{~m} / \mathrm{z}$, with a scan time of $0.2 \mathrm{~s}$. The capillary voltage was set at $2.5 \mathrm{kV}$ for negative mode, while the sample cone voltage was $40 \mathrm{~V}$. The desolvation flow rate was $900 \mathrm{~L} / \mathrm{h}$ at $400{ }^{\circ} \mathrm{C}$ and source temperature set to $100^{\circ} \mathrm{C}$. Leucine-enkephalin $([\mathrm{M}-\mathrm{H}]=m / z 554.2615)$ was used as a reference for lock mass at a frequency of $10 \mathrm{~s}$. The MS/MS spectra were obtained using collision energy ramps from 20 to $45 \mathrm{eV}$. Metabolites were identified by the Unifi software (Waters, Milford, MA, USA) with various LC/MS databases and by published papers.

\subsection{Statistical Analysis}

Statistical analyses were carried out using Win SPSS, ver22.0 (Statistical Package for the Social Science, SPSS Inc., Chicago, IL, USA). Data were expressed as the Mean \pm SD of three independent experiments. For descriptive purposes, the mean values are presented using untransformed values. The differences between the groups were determined by an independent $t$-test. A two-tailed value of $p<0.05$ was considered statistically significant.

\section{Results}

3.1. C. turczaninowii Extract Suppresses the mRNA Expression of Inflammatory Cytokines and the ER Stress Marker in hASMCs under High Glucose Conditions In Vitro

To assess the mRNA expression of pro-inflammatory cytokines (TNF- $\alpha$ and IL-6) and an endoplasmic reticulum (ER) stress marker (CHOP) in hASMCs, we performed qPCR (Figure 1). Our results showed that the mRNA levels of TNF- $\alpha$ and IL- 6 increased in $25 \mathrm{mM}$ glucose-treated hASMCs relative to the non-treated cells (Figure 1a,b), but the increased mRNA expression levels of TNF- $\alpha$ and IL- 6 was attenuated by treatment with at 1 and $10 \mu \mathrm{g} / \mathrm{mL}$ of the C. turczaninowii extract (Figure 1a,b). The mRNA level of CHOP, an ER stress marker was also increased in $25 \mathrm{mM}$ glucose-treated hASMCs relative to the non-treated cells (Figure 1c); however, the increased CHOP expression was markedly reduced by treatment with 1 and $10 \mu \mathrm{g} / \mathrm{mL}$ of $C$. turczaninowii extract, and lowered almost to the levels observed in the non-treated cells (Figure 1c). Our results indicate that the mRNA expression of pro-inflammatory cytokines and the ER stress marker, $\mathrm{CHOP}$, may be suppressed by C. turczaninowii extract treatment.
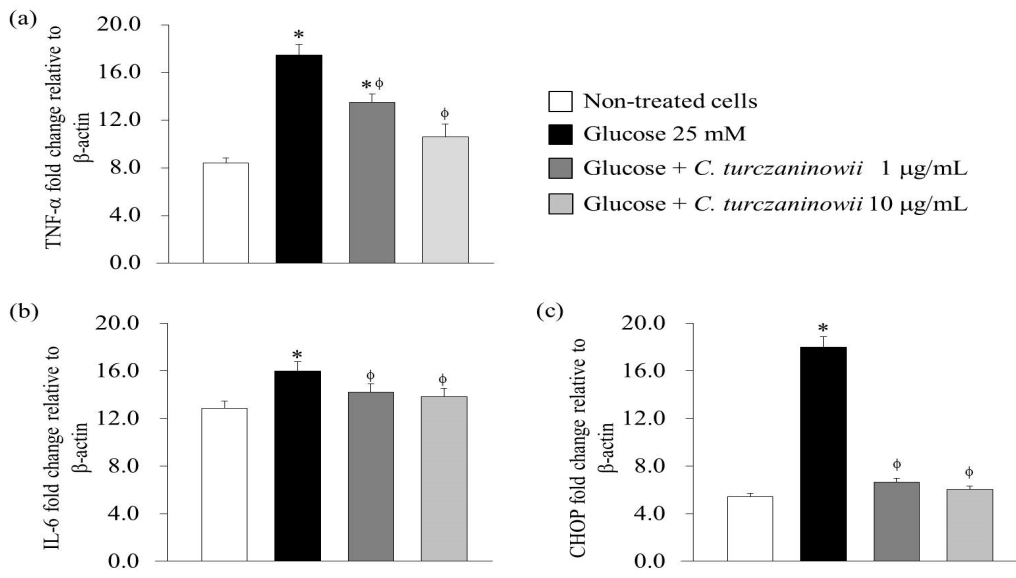
Figure 1. C. turczaninowii extract suppresses the mRNA expression of inflammatory cytokines and an endoplasmic reticulum (ER) stress marker in hASMCs under high glucose conditions in vitro. Data are expressed as mean \pm SD. ${ }^{*} p<0.05$ relative to with non-treated cells, and ${ }^{\Phi} p<0.05$ compared with glucose-stimulated cells. The mRNA levels of TNF- $\alpha(\mathbf{a})$, IL-6 (b), and CHOP (c) were measured by reverse transcription PCR. Three wells were used in each condition per experiment, and all the experiments were repeated three times. C. turczaninowii: Carpinus turczaninowii; CHOP: CCAAT-enhancer-binding proteins homologous protein; hASMCs: human aortic vascular smooth muscle cells; IL-6: interleukin-6; TNF- $\alpha$ : tumor necrosis factor- $\alpha$.

\subsection{C. turczaninowii Extract Reduces the Phosphorylation of H2.AX in hASMCs under High Glucose}

\section{Conditions In Vitro}

To determine whether high glucose-induced DNA damage in hASMCs is modulated by treatment with the $C$. turczaninowii extract, we performed immunocytochemistry to measure the expression of p-H2.AX as a marker of activated DNA damage in the cell [28]. Our results revealed that the immunoreactivity of p-H2.AX in hASMCs increased under high glucose conditions, while the increased immunoreactivity of p-H2.AX in $25 \mathrm{mM}$ glucose-treated hASMCs was attenuated by C. turczaninowii extract treatment (Figure 2A,B). Our data shows that the C. turczaninowii extract may inhibit DNA damage in hASMCs under high glucose conditions.
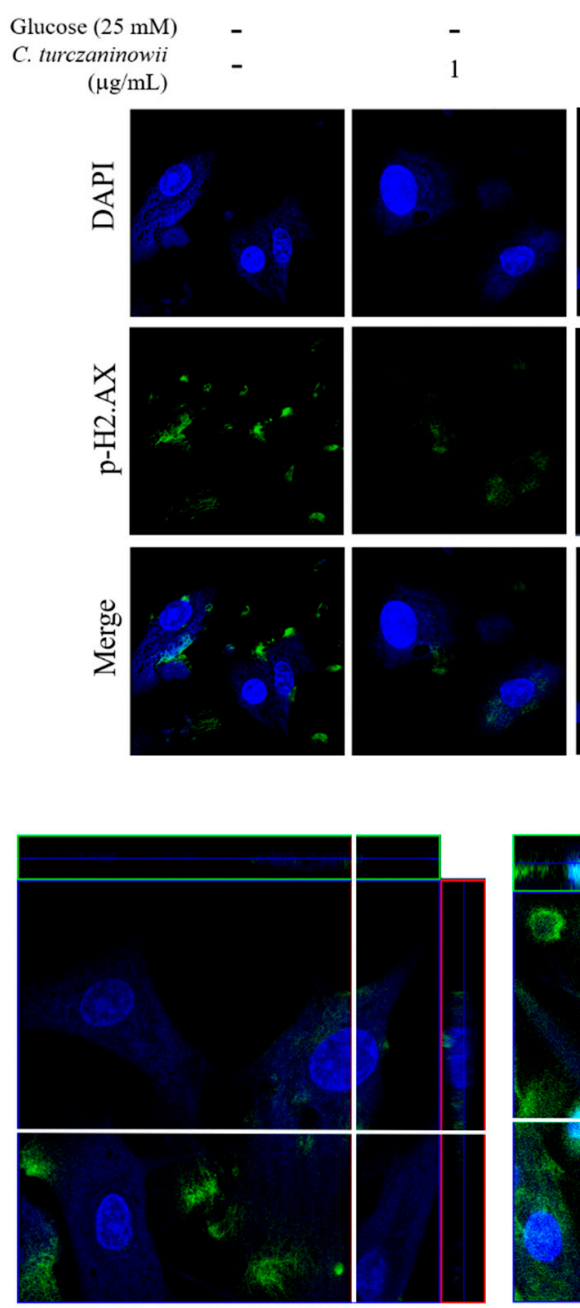

Non-treated
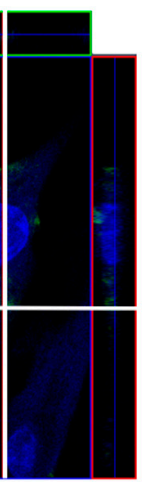

10
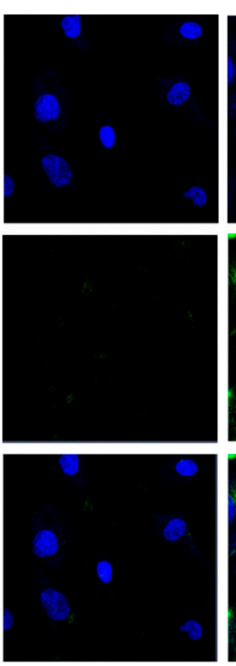

(A)

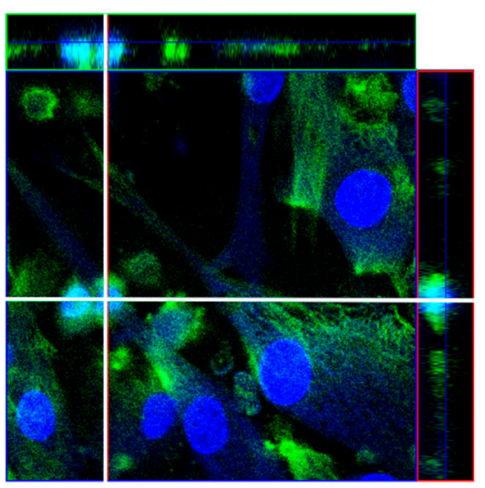

Glucose (25 mM) stimulated

(B)
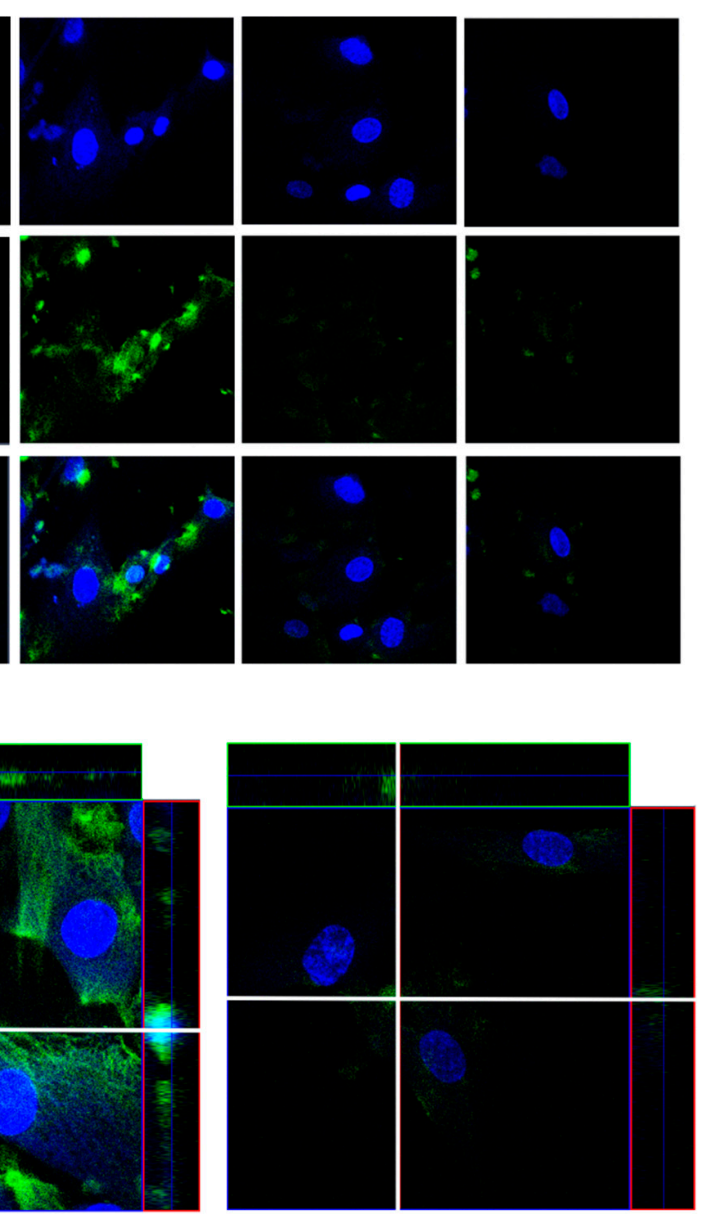

Glucose $(25 \mathrm{mM})+C$. turczaninowii $(1 \mu \mathrm{g} / \mathrm{mL})$ 
Figure 2. C. turczaninowii extract reduces the phosphorylation of $\mathrm{H} 2 . \mathrm{AX}$ in hASMCs under high glucose conditions in vitro (A) with high magnification images (B). To confirm the effect of C. turczaninowii on the phosphorylation of H2.AX in high glucose-treated hASMCs, immunofluorescence staining was performed and analyzed by confocal microscopy. C. turczaninowii: Carpinus turczaninowii; hASMCs: human aortic vascular smooth muscle cells. Phosphorylated H2.AX is represented by green staining, nuclear DNA is indicated by 40,6-diamidino-2-phenylindole (DAPI) staining (blue color), and the combined images are presented.

3.3. C. turczaninowii Extract Reduces the Expression of AMPK $\alpha 2$ in hASMCs under High Glucose Conditions In Vitro

To assess the expression of AMPK $\alpha 2$ in hASMCs under high glucose conditions, we measured mRNA levels of AMPK $\alpha 2$ in hASMCs through qPCR analysis (Figure 3). We observed a reduction in AMPK $\alpha 2$ mRNA levels in hASMCs under high glucose conditions. However, the reduced mRNA expression of AMPK $\alpha 2$ was recovered with C. turczaninowii extract treatment (Figure 3). This data indicates that the $C$. turczaninowii extract may promote the activation of AMPK signaling, and subsequently protect hASMCs against high glucose condition.

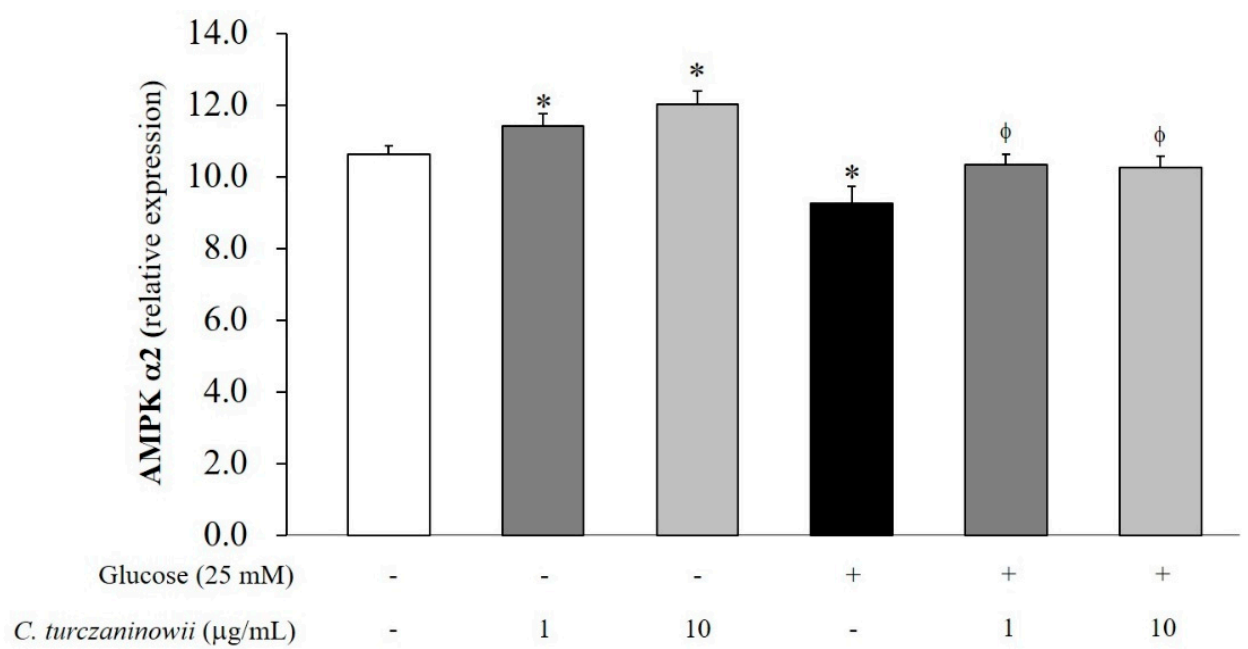

Figure 3. C. turczaninowii extract ameliorates AMP-protein activated kinase $\alpha 2$ (AMPK $\alpha 2$ ) of hASMCs under high glucose conditions in vitro. Data are expressed as mean $\pm \mathrm{SD}$. ${ }^{*} p<0.05$ relative to non-treated cells, and ${ }^{\phi} p<0.05$ relative to glucose-stimulated cells. The mRNA levels of AMPK $\alpha 2$ were measured by reverse transcription PCR. Three wells were used in each condition per experiment, and all the experiments were repeated three times. C. turczaninowii: Carpinus turczaninowii; hASMCs: human aortic vascular smooth muscle cells; AMPK $\alpha 2$ : adenosine monophosphate (AMP)-protein activated kinase $\alpha 2$; PCR: polymerase chain reaction.

3.4. UPLC-Q-TOF MS Analysis of C. turczaninowii Extract: Phenolic Components with Anti-Oxidant and Anti-Inflammation Capabilities

We performed UPLC-Q-TOF MS analysis to identify the specific components that contribute to the beneficial effect of the $C$. turczaninowii extract on hASMCs under high glucose conditions. We were able to identify 15 phenolic compounds from the $C$. turczaninowii extract (galloylquinic acid, 3,4-digalloylquinic acid, gallotannin, three unidentified ellagitannins, ellagic acid, myricitrin, quercetin 3-arabinoside, quercitrin, kaempferol 3-rhamnoside, quercetin 3-(2"'-galloylrhamnoside), 2"-O-glloylvitexin, quercetin and quercetin-3,7-dirahamnoside) (Table 1, Figure 4). Considering that these compounds are anti-oxidants [22,23,29,30], we summarize that the C. turczaninowii extract has various anti-oxidants, and may act as a modulator of inflammation. 
Table 1. Identification of phenolic compounds from C. turczaninowii extract using ultra-performance liquid chromatography-quadrupole-time of flight mass spectrometry (UPLC-Q-TOF MS).

\begin{tabular}{cccc}
\hline Retention Time (min) & Compound & $m / z[\mathbf{M}-\mathbf{H}]$ & MS Fragments \\
\hline 2.35 & Galloylquinic acid & 343.0674 & $191,169,125$ \\
2.65 & 3,4-digalloylquinic acid & 495.0782 & $343,191,169,125$ \\
2.7 & Gallotannin & 633.0726 & 407,301 \\
2.79 & Unidentified ellagitannin & 951.0701 & $615,301,273,245$ \\
2.96 & Unidentified ellagitannin & 953.0868 & $615,301,273,246$ \\
3.02 & Unidentified ellagitannin & 965.0850 & $615,301,273,247$ \\
3.12 & Ellagic acid & 300.9992 & $282,271,257$ \\
3.16 & Myricitrin & 463.0885 & $301,300,151$ \\
3.26 & Quercetin 3-arabinoside & 433.0779 & $301,300,271,255$ \\
3.32 & Quercitrin & 447.0937 & $301,300,151$ \\
3.47 & Kaempferol 3-rhamnoside & 431.0985 & $327,285,284,227,255$ \\
3.54 & Quercetin 3-(2"-galloylrhamnoside) & 599.1037 & $429,301,178,151$ \\
3.68 & 2"-O-glloylvitexin & 583.1090 & $431,345,285,125$ \\
3.78 & Quercetin & 301.0350 & $179,151,121$ \\
3.96 & Quercetin-3,7-dirahamnoside & 593.1293 & $447,301,300,151$ \\
\hline
\end{tabular}

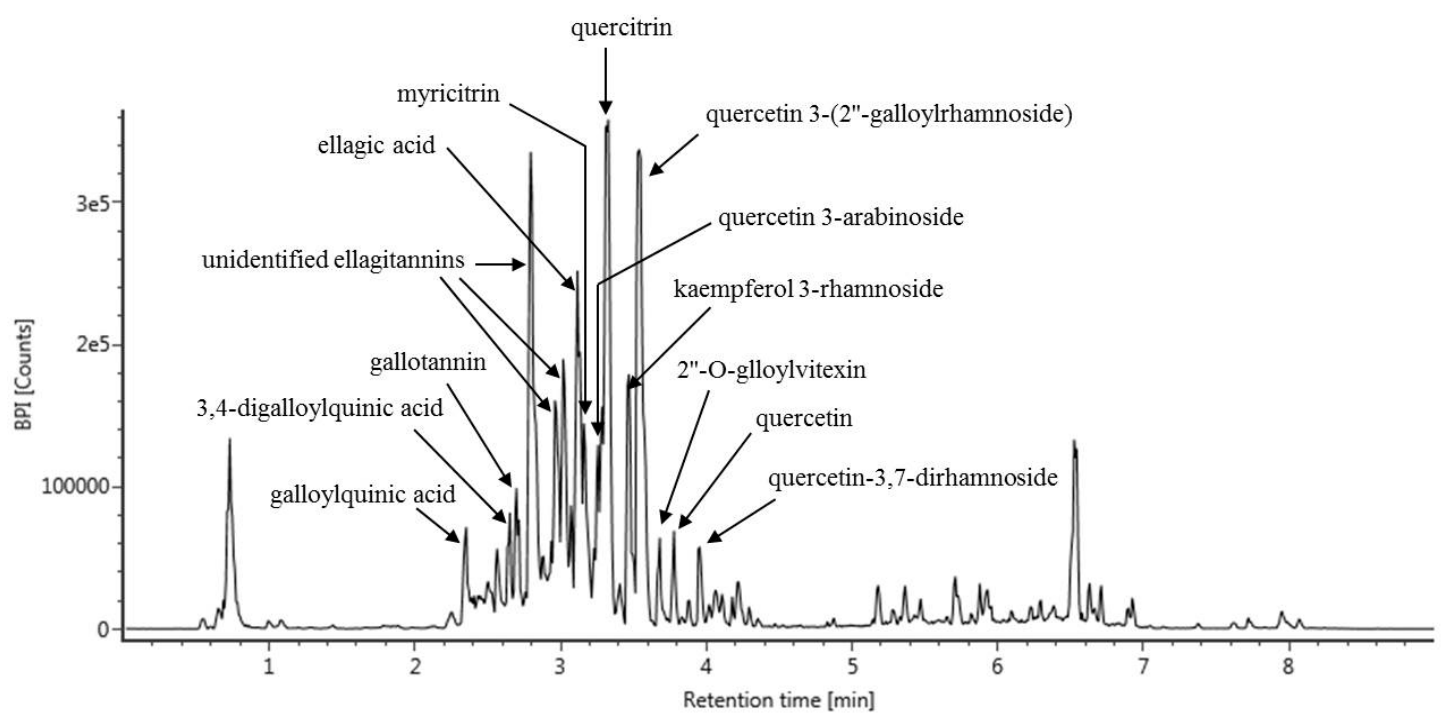

Figure 4. LC-MS chromatogram of $C$. turczaninowii extract and identification of major compounds. The extract was analyzed using a UPLC-Q-TOF MS with an Acquity UPLC BEH C 18 column $(2.1 \mathrm{~mm}$ $\times 100 \mathrm{~mm}, 1.7 \mu \mathrm{m})$ and negative electrospray ionization. The MS/MS spectra were obtained using collision energy ramps from 20 to $45 \mathrm{eV}$, and compounds were identified by the Unifi software with various LC/MS databases and by published papers. LC-MS: liquid chromatography mass spectrometry; MS/MS: tandem madss spectrometry.

\section{Discussion}

Vascular complications such as atherosclerosis are commonly observed in DM patients, and these ultimately lead to an increase in morbidity and mortality [31]. VSMCs have been known to play a critical role in the progression of diabetic vascular complications in the arterial intima [31]. Increased proliferation and migration of VSMCs aggravates the progression of atherosclerosis by converting a fatty streak to an irreversible blood plaque [11]. Several studies have demonstrated that the vascular complications caused by hyperglycemia results from abnormal proliferation and migration of VSMCs [32-34] causing DM induced atherosclerosis [34].

Many studies have attempted to discover natural compounds to treat vascular complications because of the relatively low occurrence of the adverse effects of these compounds when compared 
with the artificial drugs [35-37]. In this study, we observed that hASMCs under high glucose conditions remained viable when treated with $C$. turczaninowii at low concentrations (1 and $10 \mu \mathrm{g} / \mathrm{mL}$ ). Considering that hyperglycemia reduces cellular function and viability [38], the protective effect of $C$. turczaninowii is necessary to attenuate the cellular damage of diabetic VSMCs. Furthermore, we found that increased expression of $\mathrm{p}-\mathrm{H} 2$.AX in hASMCs under high glucose conditions was dramatically attenuated by C. turczaninowii treatment. These data indicate that $C$. turczaninowii may be protective against the DNA damage observed during hyperglycemia. Increased p-H2.AX indicates an increase in DNA damage in VSMCs [39], and suggests the activation of various inflammatory signaling in responses to the DNA double-strand breaks [40]. Oxidative stress promotes apoptosis of VSMCs [41]; therefore, we hypothesized that $C$. turczaninowii at low concentrations may inhibit apoptosis of VSMCs by modulating $\mathrm{p}-\mathrm{H} 2$.AX even under high glucose-induced oxidative stress. However, $\mathrm{p}-\mathrm{H} 2$.AX staining was also found in cytosol, as well as in the nuclei under high glucose condition. According to the report by Jung et al. [42], $\gamma \mathrm{H} 2$.AX could be induced in cytosol as well as nucleus upon DNA damage when TrkA was overexpressed. TrkA plays an important role in cell survival/differentiation, and apoptosis, and could exhibit pleiotropic effects in nonneuronal cells when its protein level is high, even in the absence of its ligand binding [42]. In addition, Okamura et al reported that histone H1.2 can be translocated to mitochodria and associated with Bak, leading to apoptotic cell death (bleomycin-treated human squamous carcinoma cells) [43]. Although the reason why $\gamma \mathrm{H} 2 \mathrm{AX}$ is induced in cytosol and how it leads to cell death is unclear, we assumed that $\gamma \mathrm{H} 2 \mathrm{AX}$ cytosolic accumulation may be involved in the choice of cell death together with its role in nucleic DNA damage. Future study is needed to identify the phosphorylated H2.AX observed in cytosol.

Moreover, this study shows that $C$. turczaninowii attenuates the increased expression of pro-inflammatory cytokines (TNF- $\alpha$ and IL-6) and ER stress response (CHOP) genes in hASMCs under high glucose condition. TNF- $\alpha$, a major inflammatory cytokine, plays a critical role in vascular atherosclerosis [44,45], and is expressed by VSMCs in atheromatous plaques [46]. It can boost the pro-apoptotic effect by activating monocytes, endothelial cells, and macrophages, and can be considered as an inflammatory index that indicates accelerated atherosclerosis [47-49]. TNF- $\alpha$ also stimulates VSMC proliferation and migration in blood vessels [50]. In addition, IL-6 promotes the growth and migration of VSMCs via the induction of PDGF production [51-53], and is related to cytoskeletal reorganization [54]. Given our results, we hypothesize that $C$. turczaninowii may lessen the inflammatory responses, inhibit apoptosis of VSMCs, and reduce the migration and proliferation of VSMCs.

ER stress is known to be enhanced in arterial SMCs in response to atherosclerosis risk factors $[55,56]$. Several studies have demonstrated the expression of Grp78 as an ER stress marker in atherosclerotic lesions [57], and the increased expression of ER chaperones was found in VSMCs in atherosclerotic plaques [55]. The proliferation of VMSCs plays a critical role in plaque progression [58]. Based on our results, C. turczaninowii may alleviate ER stress response and ultimately inhibit the migration of VSMCs which leads to the formation of plaques.

In addition, AMPK consisting of three $\alpha, \beta$, and $\gamma$ subunits allows cells to sense changes in their energy status $[59,60]$. The $\alpha$ subunit has catalytic kinase domain that transfers phosphate from ATP to the target protein [61]. Phosphorylation of $\mathrm{Thr}^{172}$ on the $\alpha$ subunit of AMPK ultimately activates AMPK [61,62]. Recent studies have demonstrated that AMPK-mediated cellular signaling plays a protective role in CVD $[63,64]$. The phosphorylation of AMPK results in increased glucose uptake and metabolism, and fatty acid oxidation [65]. The activation of AMPK has been reported to block the migration of VSMCs through the regulation of cytoskeletal stability [66]. Based on these evidences, the modulation of AMPK activation can be highlighted as a target for the treatment of obesity and T2DM [67]. Especially, AMPK $\alpha 2$ is an important modulator in the migration and proliferation of VSMCs [68]. Deletion of AMPK $\alpha 2$ triggers aberrant activation of nicotinamide adenine dinucleotide phosphate oxidase, leads to endothelial dysfunction [69], and results in the increased risk of atherosclerosis [64]. Some studies have reported that deficiency of AMPK $\alpha 2$ aggravates VSMC damage [68] and promotes migration of VSMCs [70,71]. Moreover, deletion of AMPK $\alpha 2$ activates the 
nuclear factor кB2 (NF-kB2)/p52 NF-kB signaling [68,72]. Considering our results, we assume that $C$. turczaninowii may inhibit VSMC damage via the activation of AMPK under hyperglycemic condition. However, we need further study for the measurement of p-AMPK using Western blotting to elucidate clear mechanism.

Previous studies have identified chemical compounds of $C$. turczaninowii branches, but which were limited to a few compounds such as naringenin and quercetin glycosides (flavonoids) together with carpinotriols A and B $[22,23,25]$. In this study, we analyzed components in C. turczaninowii using UPLC-Q-TOF MS. We identified 15 types of phenolic components from C. turczaninowii including quercetin, myricitrin, and ellagic acid in major proportions. Quercetin (3,5,7,30,40-tetrahydroxyflavone), which is a commonly distributed plant flavonoid, has been reported to display biological properties including anti-oxidant [73], anti-inflammation [74], and anti-viral properties [75] against CVD [76]. Moreover, quercetin has been known to alleviate cell apoptosis and reduce ER stress response in vascular endothelial cells under high glucose condition [29]. One study demonstrated that quercetin also suppresses atherosclerotic inflammation by modulating NF-kB signaling [77]. In addition, myricitrin, as a plant flavonoid, is distributed in the roots of Myrica esculenta, Myrica cerifera, Nymphaea lotus, and some other plants [78]. Myricitrin has been reported to possess anti-oxidative and anti-inflammatory properties, and also protects various cells against stress condition [79]. It has been known to block the expression of vascular adhesion molecule in TNF- $\alpha$-stimulated VSMCs [80], alleviate apoptosis of endothelial cells, and prevent the onset of atherosclerosis [81]. Recent studies have demonstrated that myricitrin exerts anti-oxidant function in the cells under hyperglycemia induced oxidative stress condition [82]. Furthermore, ellagic acid (2,3,7,8-tetrahydroxybenzopyrano [5,4,3-cde] benzopyran-5-10-dione) as a phenolic natural compound is abundantly present in fruits and nuts such as blueberries and walnuts [83,84]. Previous studies have reported the protective effect of ellagic acid based on its superoxide and hydroxide scavenging [85,86], anti-oxidant, and anti-inflammatory properties [87-89]. As mentioned above, all the main components of C. turczaninowii that were analyzed have anti-oxidant and anti-inflammatory properties. We need further studies on animal and human models to elucidate the major component of $C$. turczaninowii among the identified ones, which contributes to arterial protection.

\section{Conclusions}

Given the evidence presented above, C. turczaninowii may be an effective anti-oxidant and anti-inflammatory regulator to protect VSMCs against hyperglycemia-induced damage. In addition, we suggest that $C$. turczaninowii should be noted as a natural therapeutic compound to prevent and treat atherosclerosis in patients with hyperglycemia and/or diabetes.

Author Contributions: All the authors were involved in the development of the study protocol and the experimental design. All the authors read, commented on, and contributed to the submitted manuscript. Sample collection and experiments were performed by J.S., S.R.Y., Y.K.S., W.Y.B., C.-H.B., J.-H.Y., and O.Y.K. Data were analyzed by S.R.Y., H.-J.K., and O.Y.K. The manuscript was written by J.S. and O.Y.K. and finalized by H.-J.K. and O.Y.K. The authors declare that they have no competing interests.

Funding: This study was supported by the National Institute of Biological Resources (NIBR), funded by the Ministry of Environmental of the Republic of Korea (NIBR201527101), the National Research Foundation of Korea Grant funded by the Korean Government (2016R1A2B4013627, and 2016R1D1A1B03930394), and partly supported by Chonnam National University (2017-2859).

Conflicts of Interest: The authors declare no conflict of interest. 


\section{References}

1. Haffner, S.M.; Lehto, S.; Ronnemaa, T.; Pyorala, K.; Laakso, M. Mortality from coronary heart disease in subjects with type 2 diabetes and in nondiabetic subjects with and without prior myocardial infarction. N. Engl. J. Med. 1998, 339, 229-234. [CrossRef] [PubMed]

2. The Emerging Risk Factors Collaboration; Sarwar, N.; Gao, P.; Seshasai, S.R.; Gobin, R.; Kaptoge, S.; Di Angelantonio, E.; Ingelsson, E.; Lawlor, D.A.; Selvin, E.; et al. Diabetes mellitus, fasting blood glucose concentration, and risk of vascular disease: A collaborative meta-analysis of 102 prospective studies. Lancet 2010, 375, 2215-2222. [CrossRef]

3. Zhang, Y.; Shi, H.; Sun, G.; Li, S.; Xu, X.; Ye, C.; Li, X.; Wang, S. High glucose induces dysfunction and apoptosis in endothelial cells: Is the effect of high glucose persistence more important than concentration? Exp. Clin. Endocrinol. Diabetes Off. J. Ger. Soc. Endocrinol. Ger. Diabetes Assoc. 2011, 119, 225-233. [CrossRef] [PubMed]

4. Tong, X.; Ying, J.; Pimentel, D.R.; Trucillo, M.; Adachi, T.; Cohen, R.A. High glucose oxidizes SERCA cysteine-674 and prevents inhibition by nitric oxide of smooth muscle cell migration. J. Mol. Cell. Cardiol. 2008, 44, 361-369. [CrossRef] [PubMed]

5. Creager, M.A.; Luscher, T.F.; Cosentino, F.; Beckman, J.A. Diabetes and vascular disease: Pathophysiology, clinical consequences, and medical therapy: Part I. Circulation 2003, 108, 1527-1532. [CrossRef] [PubMed]

6. Ding, H.; Triggle, C.R. Endothelial cell dysfunction and the vascular complications associated with type 2 diabetes: Assessing the health of the endothelium. Vasc. Health Risk Manag. 2005, 1, 55-71. [CrossRef] [PubMed]

7. Katakami, N. Mechanism of Development of Atherosclerosis and Cardiovascular Disease in Diabetes Mellitus. J. Atheroscler. Thromb. 2018, 25, 27-39. [CrossRef]

8. Giugliano, D.; Ceriello, A.; Paolisso, G. Oxidative stress and diabetic vascular complications. Diabetes Care 1996, 19, 257-267. [CrossRef]

9. Nishikawa, T.; Edelstein, D.; Du, X.L.; Yamagishi, S.; Matsumura, T.; Kaneda, Y.; Yorek, M.A.; Beebe, D.; Oates, P.J.; Hammes, H.P.; et al. Normalizing mitochondrial superoxide production blocks three pathways of hyperglycaemic damage. Nature 2000, 404, 787-790. [CrossRef]

10. Baynes, J.W.; Thorpe, S.R. Role of oxidative stress in diabetic complications: A new perspective on an old paradigm. Diabetes 1999, 48, 1-9. [CrossRef]

11. Bornfeldt, K.E.; Tabas, I. Insulin resistance, hyperglycemia, and atherosclerosis. Cell Metab. 2011, 14, 575-585. [CrossRef] [PubMed]

12. Wolff, S.P. Diabetes mellitus and free radicals. Free radicals, transition metals and oxidative stress in the aetiology of diabetes mellitus and complications. Br. Med. Bull. 1993, 49, 642-652. [CrossRef] [PubMed]

13. Orasanu, G.; Plutzky, J. The pathologic continuum of diabetic vascular disease. J. Am. Coll. Cardiol. 2009, 53, S35-S42. [CrossRef] [PubMed]

14. Steinert, J.R.; Wyatt, A.W.; Jacob, R.; Mann, G.E. Redox modulation of Ca2+ signaling in human endothelial and smooth muscle cells in pre-eclampsia. Antioxid. Redox Signal. 2009, 11, 1149-1163. [CrossRef] [PubMed]

15. Matough, F.A.; Budin, S.B.; Hamid, Z.A.; Alwahaibi, N.; Mohamed, J. The role of oxidative stress and antioxidants in diabetic complications. Sultan Qaboos Univ. Med. J. 2012, 12, 5-18. [CrossRef] [PubMed]

16. Dominguez, C.; Ruiz, E.; Gussinye, M.; Carrascosa, A. Oxidative stress at onset and in early stages of type 1 diabetes in children and adolescents. Diabetes Care 1998, 21, 1736-1742. [CrossRef]

17. Sano, T.; Umeda, F.; Hashimoto, T.; Nawata, H.; Utsumi, H. Oxidative stress measurement by in vivo electron spin resonance spectroscopy in rats with streptozotocin-induced diabetes. Diabetologia 1998, 41, 1355-1360. [CrossRef]

18. Marazza, J.A.; Garro, M.S.; de Giori, G.S. Aglycone production by Lactobacillus rhamnosus CRL981 during soymilk fermentation. Food Microbiol. 2009, 26, 333-339. [CrossRef]

19. Jin, T.; Kim, O.Y.; Shin, M.J.; Choi, E.Y.; Lee, S.S.; Han, Y.S.; Chung, J.H. Fisetin up-regulates the expression of adiponectin in 3T3-L1 adipocytes via the activation of silent mating type information regulation 2 homologue 1 (SIRT1)-deacetylase and peroxisome proliferator-activated receptors (PPARs). J. Agric. Food Chem. 2014, 62, 10468-10474. [CrossRef] 
20. Moon, J.; Do, H.J.; Kim, O.Y.; Shin, M.J. Antiobesity effects of quercetin-rich onion peel extract on the differentiation of 3T3-L1 preadipocytes and the adipogenesis in high fat-fed rats. Food Chem. Toxicol. Int. J. Publ. Br. Ind. Biol. Res. Assoc. 2013, 58, 347-354. [CrossRef]

21. Yang, E.J.; Yim, E.Y.; Song, G.; Kim, G.O.; Hyun, C.G. Inhibition of nitric oxide production in lipopolysaccharide-activated RAW 264.7 macrophages by Jeju plant extracts. Interdiscip. Toxicol. 2009, 2, 245-249. [CrossRef] [PubMed]

22. Ko, H.N.; Oh, T.H.; Baik, J.S.; Hyun, C.G.; Kim, S.S.; Lee, N.H. Anti-inflammatory activities for the extracts and Carpinontriols from branches of Caripinus Turczaninowii. Int. J. Pharmacol. 2013, 9, 157-163.

23. Ko, H.N.; Kim, J.M.; Bu, H.J.; Lee, H.H. Chemical constituents from the branches of Carpinus turczaninowii with antioxidative activities. J. Korean Chem. Soc. 2013, 57, 520-522. [CrossRef]

24. Kang, J.M. Identification of Anti-Oxidative, Skin Whitening, Anti-Inflammatory and Anti-Bacterial Constituents from the Leaves of Carpinus turczaninowii Hance. Master's Thesis, Jeju National University, Jeju, Korea, 2015.

25. Jeon, J.I.; Jang, J.S. Foliar flavonoids of genus Carpinus in eastern Asia primarily based on native taxa to Korea. Korean J. Plant. Tax. 2000, 30, 139-153. [CrossRef]

26. Chang, C.S.; Chang, K.S. Typification of Corylopsis coreana (Hamamelidaceae) and Carpinus laxiflora var. longispica (Betulaceae). J. Jpn. Bot. 2010, 85, 270-276.

27. Yeo, J.H.; Son, Y.K.; Bang, W.Y.; Kim, O.Y. Carpinus truczaninowii extract showed anti-inflammatory response on human aortic vascular smooth muscle cells. Planta Med. 2016, 82, S1-S381. [CrossRef]

28. Gray, K.; Kumar, S.; Figg, N.; Harrison, J.; Baker, L.; Mercer, J.; Littlewood, T.; Bennett, M. Effects of DNA damage in smooth muscle cells in atherosclerosis. Circ. Res. 2015, 116, 816-826. [CrossRef] [PubMed]

29. Cai, X.; Bao, L.; Ding, Y.; Dai, X.; Zhang, Z.; Li, Y. Quercetin alleviates cell apoptosis and inflammation via the ER stress pathway in vascular endothelial cells cultured in high concentrations of glucosamine. Mol. Med. Rep. 2017, 15, 825-832. [CrossRef] [PubMed]

30. Zhao, L.R.; Du, Y.J.; Chen, L.; Liu, Z.G.; Pan, Y.H.; Liu, J.F.; Liu, B. Quercetin protects against high glucose-induced damage in bone marrow-derived endothelial progenitor cells. Int. J. Mol. Med. 2014, 34, 1025-1031. [CrossRef]

31. Nathan, D.M.; Lachin, J.; Cleary, P.; Orchard, T.; Brillon, D.J.; Backlund, J.Y.; O’Leary, D.H.; Genuth, S.; Diabetes Control and Complications Trial; Epidemiology of Diabetes Interventions and Complications Research Group. Intensive diabetes therapy and carotid intima-media thickness in type 1 diabetes mellitus. N. Engl. J. Med. 2003, 348, 2294-2303.

32. Popov DConstantinescu, E. Arterial smooth muscle cells dysfunction in hyperglycaemia and hyperglycaemia associated with hyperlipidaemia: From causes to effects. Archiv. Physiol. Biochem. 2008, 114, 150-160. [CrossRef]

33. Rizzoni, D.; Rosei, E.A. Small artery remodeling in diabetes mellitus. Nutr. Metab. Cardiovasc. Dis. 2009, 19, 587-592. [CrossRef] [PubMed]

34. Jie, W.; Wang, X.; Zhang, Y.; Guo, J.; Kuang, D.; Zhu, P.; Wang, G.; Ao, Q. SDF-1alpha/CXCR4 axis is involved in glucose-potentiated proliferation and chemotaxis in rat vascular smooth muscle cells. Int. J. Exp. Pathol. 2010, 91, 436-444. [CrossRef] [PubMed]

35. Timimi, F.K.; Ting, H.H.; Haley, E.A.; Roddy, M.A.; Ganz, P.; Creager, M.A. Vitamin C improves endothelium-dependent vasodilation in patients with insulin-dependent diabetes mellitus. J. Am. Coll. Cardiol. 1998, 31, 552-557. [CrossRef]

36. Teede, H.J.; Giannopoulos, D.; Dalais, F.S.; Hodgson, J.; McGrath, B.P. Randomised, controlled, cross-over trial of soy protein with isoflavones on blood pressure and arterial function in hypertensive subjects. J. Am. Coll. Nutr. 2006, 25, 533-540. [CrossRef]

37. Reshef, N.; Hayari, Y.; Goren, C.; Boaz, M.; Madar, Z.; Knobler, H. Antihypertensive effect of sweetie fruit in patients with stage I hypertension. Am. J. Hypertens. 2005, 18, 1360-1363. [CrossRef] [PubMed]

38. Safi, S.Z.; Qvist, R.; Yan, G.O.; Ismail, I.S. Differential expression and role of hyperglycemia induced oxidative stress in epigenetic regulation of beta1, beta2 and beta3-adrenergic receptors in retinal endothelial cells. BMC Med. Genom. 2014, 7, 29. [CrossRef] [PubMed]

39. Cafueri, G.; Parodi, F.; Pistorio, A.; Bertolotto, M.; Ventura, F.; Gambini, C.; Bianco, P.; Dallegri, F.; Pistoia, V.; Pezzolo, A.; et al. Endothelial and smooth muscle cells from abdominal aortic aneurysm have increased oxidative stress and telomere attrition. PLoS ONE 2012, 7, e35312. [CrossRef] 
40. Rogakou, E.P.; Boon, C.; Redon, C.; Bonner, W.M. Megabase chromatin domains involved in DNA double-strand breaks in vivo. J. Cell. Biol. 1999, 146, 905-916. [CrossRef] [PubMed]

41. Satoh, K.; Nigro, P.; Berk, B.C. Oxidative stress and vascular smooth muscle cell growth: A mechanistic linkage by cyclophilin A. Antioxid. Redox Signal. 2010, 12, 675-682. [CrossRef]

42. Jung, E.J.; Kim, C.W.; Kim, D.R. Cytosolic accumulation of $\gamma \mathrm{H} 2 \mathrm{AX}$ is associated with tropomyosin-related kinase A-induced cell death in U2OS cell. Exp. Mol. Med. 2008, 40, 276-285. [CrossRef] [PubMed]

43. Okamura, H.; Yoshida, K.; Amorim, B.R.; Haneji, T. Histone H1.2 is translocated to mitochondria and associates with bak in bleomycin-induced apoptotic cells. J. Cell. Biochem. 2008, 103, 1488-1496. [CrossRef] [PubMed]

44. Balkwill, F. Tumour necrosis factor and cancer. Nat. Rev. Cancer 2009, 9, 361-371. [CrossRef] [PubMed]

45. Beg, A.A.; Baltimore, D. An essential role for NF-kappaB in preventing TNF-alpha-induced cell death. Science 1996, 274, 782-784. [CrossRef] [PubMed]

46. Prins, J.B.; Ledgerwood, E.C.; Ameloot, P.; Vandenabeele, P.; Faraco, P.R.; Bright, N.A.; O’Rahilly, S.; Bradley, J.R. Tumor necrosis factor-induced cytotoxicity is not related to rates of mitochondrial morphological abnormalities or autophagy-changes that can be mediated by TNFR-I or TNFR-II. Biosci. Rep. 1998, 18, 329-340. [CrossRef]

47. Rakesh, K.; Agrawal, D.K. Cytokines and growth factors involved in apoptosis and proliferation of vascular smooth muscle cells. Int. Immunopharmacol. 2005, 5, 1506. [CrossRef]

48. McKellar, G.E.; McCarey, D.W.; Sattar, N.; McInnes, I.B. Role for TNF in atherosclerosis? Lessons from autoimmune disease. Nat. Rev. Cardiol. 2009, 6, 410-417. [CrossRef]

49. Sprague, A.H.; Khalil, R.A. Inflammatory cytokines in vascular dysfunction and vascular disease. Biochem. Pharmacol. 2009, 78, 539-552. [CrossRef]

50. Selzman, C.H.; Shames, B.D.; McIntyre, R.C., Jr.; Banerjee, A.; Harken, A.H. The NFkappaB inhibitory peptide, IkappaBalpha, prevents human vascular smooth muscle proliferation. Ann. Thorac. Surg. 1999, 67, 1227-1231; discussion 1231-1232. [CrossRef]

51. Zhang, H.; Park, Y.; Wu, J.; Chen, X.; Lee, S.; Yang, J.; Dellsperger, K.C.; Zhang, C. Role of TNF-alpha in vascular dysfunction. Clin. Sci. 2009, 116, 219-230. [CrossRef]

52. Geng, Y.J.; Wu, Q.; Muszynski, M.; Hansson, G.K.; Libby, P. Apoptosis of vascular smooth muscle cells induced by in vitro stimulation with interferon-gamma, tumor necrosis factor-alpha, and interleukin-1 beta. Arterioscler. Thromb. Vasc. Biol. 1996, 16, 19-27. [CrossRef] [PubMed]

53. Ikeda, U.; Ikeda, M.; Oohara, T.; Oguchi, A.; Kamitani, T.; Tsuruya, Y.; Kano, S. Interleukin 6 stimulates growth of vascular smooth muscle cells in a PDGF-dependent manner. Am. J. Physiol. 1991, 260, H1713-H1717. [CrossRef] [PubMed]

54. Wang, Z.; Newman, W.H. Smooth muscle cell migration stimulated by interleukin 6 is associated with cytoskeletal reorganization. J. Surg. Res. 2003, 111, 261-266. [CrossRef]

55. Khan, M.I.; Pichna, B.A.; Shi, Y.; Bowes, A.J.; Werstuck, G.H. Evidence supporting a role for endoplasmic reticulum stress in the development of atherosclerosis in a hyperglycaemic mouse model. Antioxid. Redox Signal. 2009, 11, 2289-2298. [CrossRef] [PubMed]

56. Werstuck, G.H.; Khan, M.I.; Femia, G.; Kim, A.J.; Tedesco, V.; Trigatti, B.; Shi, Y. Glucosamine-induced endoplasmic reticulum dysfunction is associated with accelerated atherosclerosis in a hyperglycemic mouse model. Diabetes 2006, 55, 93-101. [CrossRef] [PubMed]

57. Zhou, J.; Werstuck, G.H.; Lhotak, S.; de Koning, A.B.; Sood, S.K.; Hossain, G.S.; Moller, J.; Ritskes-Hoitinga, M.; Falk, E.; Dayal, S.; et al. Association of multiple cellular stress pathways with accelerated atherosclerosis in hyperhomocysteinemic apolipoprotein E-deficient mice. Circulation 2004, 110, 207-213. [CrossRef]

58. Bennett, M.R.; Sinha, S.; Owens, G.K. Vascular Smooth Muscle Cells in Atherosclerosis. Circ. Res. 2016, 118, 692-702. [CrossRef] [PubMed]

59. Lee-Young, R.S.; Griffee, S.R.; Lynes, S.E.; Bracy, D.P.; Ayala, J.E.; McGuinness, O.P.; Wasserman, D.H. Skeletal muscle AMP-activated protein kinase is essential for the metabolic response to exercise in vivo. J. Biol. Chem. 2009, 284, 23925-23934. [CrossRef]

60. Kemp, B.E.; Stapleton, D.; Campbell, D.J.; Chen, Z.P.; Murthy, S.; Walter, M.; Gupta, A.; Adams, J.J.; Katsis, F.; van Denderen, B.; et al. AMP-activated protein kinase, super metabolic regulator. Biochem. Soc. Trans. 2003, 31, 162-168. [CrossRef] 
61. Hawley, S.A.; Selbert, M.A.; Goldstein, E.G.; Edelman, A.M.; Carling, D.; Hardie, D.G. 5'-AMP activates the AMP-activated protein kinase cascade, and $\mathrm{Ca} 2+/$ calmodulin activates the calmodulin-dependent protein kinase I cascade, via three independent mechanisms. J. Biol. Chem. 1995, 270, 27186-27191. [CrossRef]

62. Shaw, R.J.; Kosmatka, M.; Bardeesy, N.; Hurley, R.L.; Witters, L.A.; DePinho, R.A.; Cantley, L.C. The tumor suppressor LKB1 kinase directly activates AMP-activated kinase and regulates apoptosis in response to energy stress. Proc. Natl. Acad. Sci. USA 2004, 101, 3329-3335. [CrossRef] [PubMed]

63. Dong, Y.; Zhang, M.; Wang, S.; Liang, B.; Zhao, Z.; Liu, C.; Wu, M.; Choi, H.C.; Lyons, T.J.; Zou, M.H. Activation of AMP-activated protein kinase inhibits oxidized LDL-triggered endoplasmic reticulum stress in vivo. Diabetes 2010, 59, 1386-1396. [CrossRef] [PubMed]

64. Dong, Y.; Zhang, M.; Liang, B.; Xie, Z.; Zhao, Z.; Asfa, S.; Choi, H.C.; Zou, M.H. Reduction of AMP-activated protein kinase alpha2 increases endoplasmic reticulum stress and atherosclerosis in vivo. Circulation 2010, 121, 792-803. [CrossRef] [PubMed]

65. Hardie, D.G. The AMP-activated protein kinase pathway-new players upstream and downstream. J. Cell Sci. 2004, 117, 5479-5487. [CrossRef] [PubMed]

66. Stone, J.D.; Narine, A.; Shaver, P.R.; Fox, J.C.; Vuncannon, J.R.; Tulis, D.A. AMP-activated protein kinase inhibits vascular smooth muscle cell proliferation and migration and vascular remodeling following injury. Am. J. Physiol. Heart Circ. Physiol. 2013, 304, H369-H381. [CrossRef] [PubMed]

67. Winder, W.W.; Hardie, D.G. AMP-activated protein kinase, a metabolic master switch: Possible roles in type 2 diabetes. Am. J. Physiol. 1999, 277, E1-E10. [CrossRef]

68. Song, P.; Wang, S.; He, C.; Wang, S.; Liang, B.; Viollet, B.; Zou, M.H. AMPKalpha2 deletion exacerbates neointima formation by upregulating Skp2 in vascular smooth muscle cells. Circ. Res. 2011, 109, 1230-1239. [CrossRef]

69. Wang, S.; Zhang, M.; Liang, B.; Xu, J.; Xie, Z.; Liu, C.; Viollet, B.; Yan, D.; Zou, M.H. AMPKalpha2 deletion causes aberrant expression and activation of $\mathrm{NAD}(\mathrm{P}) \mathrm{H}$ oxidase and consequent endothelial dysfunction in vivo: Role of $26 \mathrm{~S}$ proteasomes. Circ. Res. 2010, 106, 1117-1128. [CrossRef]

70. Mirouse, V.; Swick, L.L.; Kazgan, N.; St Johnston, D.; Brenman, J.E. LKB1 and AMPK maintain epithelial cell polarity under energetic stress. J. Cell Biol. 2007, 177, 387-392. [CrossRef]

71. Jansen, M.; Ten Klooster, J.P.; Offerhaus, G.J.; Clevers, H. LKB1 and AMPK family signaling: The intimate link between cell polarity and energy metabolism. Physiol. Rev. 2009, 89, 777-798. [CrossRef]

72. Barre, B.; Perkins, N.D. The Skp2 promoter integrates signaling through the NF-kappaB, p53, and Akt/GSK3beta pathways to regulate autophagy and apoptosis. Mol. Cell 2010, 38, 524-538. [CrossRef] [PubMed]

73. Zhang, M.; Swarts, S.G.; Yin, L.; Liu, C.; Tian, Y.; Cao, Y.; Swarts, M.; Yang, S.; Zhang, S.B.; Zhang, K.; et al. Antioxidant properties of quercetin. Adv. Exp. Med. Biol. 2011, 701, 283-289. [PubMed]

74. Boots, A.W.; Wilms, L.C.; Swennen, E.L.; Kleinjans, J.C.; Bast, A.; Haenen, G.R. In vitro and ex vivo anti-inflammatory activity of quercetin in healthy volunteers. Nutrition 2008, 24, 703-710. [CrossRef] [PubMed]

75. Davis, J.M.; Murphy, E.A.; McClellan, J.L.; Carmichael, M.D.; Gangemi, J.D. Quercetin reduces susceptibility to influenza infection following stressful exercise. Am. J. Physiol. Regul. Integr. Comp. Physiol. 2008, 295, R505-R509. [CrossRef] [PubMed]

76. Russo, M.; Spagnuolo, C.; Tedesco, I.; Bilotto, S.; Russo, G.L. The flavonoid quercetin in disease prevention and therapy: Facts and fancies. Biochem. Pharmacol. 2012, 83, 6-15. [CrossRef] [PubMed]

77. Bhaskar, S.; Sudhakaran, P.R.; Helen, A. Quercetin attenuates atherosclerotic inflammation and adhesion molecule expression by modulating TLR-NF-kappaB signaling pathway. Cell. Immunol. 2016, 310, 131-140. [CrossRef] [PubMed]

78. Meotti, F.C.; Senthilmohan, R.; Harwood, D.T.; Missau, F.C.; Pizzolatti, M.G.; Kettle, A.J. Myricitrin as a substrate and inhibitor of myeloperoxidase: Implications for the pharmacological effects of flavonoids. Free Radic. Biol. Med. 2008, 44, 109-120. [CrossRef]

79. Yokomizo, A.; Moriwaki, M. Myricitrin degraded by simulated digestion inhibits oxidation of human low-density lipoprotein. Biosci. Biotechnol. Biochem. 2005, 69, 693-699. [CrossRef]

80. Yan, L.J.; Yang, H.T.; Duan, H.Y.; Wu, J.T.; Qian, P.; Fan, X.W.; Wang, S. Myricitrin inhibits vascular adhesion molecule expression in TNFalphastimulated vascular smooth muscle cells. Mol. Med. Rep. 2017, 16, 6354-6359. [CrossRef] 
81. Qin, M.; Luo, Y.; Meng, X.B.; Wang, M.; Wang, H.W.; Song, S.Y.; Ye, J.X.; Pan, R.L.; Yao, F.; Wu, P.; et al. Myricitrin attenuates endothelial cell apoptosis to prevent atherosclerosis: An insight into PI3K/Akt activation and STAT3 signaling pathways. Vasc. Pharmacol. 2015, 70, 23-34. [CrossRef]

82. Ahangarpour, A.; Oroojan, A.A.; Khorsandi, L.; Kouchak, M.; Badavi, M. Antioxidant effect of myricitrin on hyperglycemia-induced oxidative stress in C2C12 cell. Cell Stress Chaperones 2018, 23, 773-781. [CrossRef] [PubMed]

83. Anderson, K.J.; Teuber, S.S.; Gobeille, A.; Cremin, P.; Waterhouse, A.L.; Steinberg, F.M. Walnut polyphenolics inhibit in vitro human plasma and LDL oxidation. J. Nutr. 2001, 131, 2837-2842. [CrossRef] [PubMed]

84. Wada, L.; Ou, B. Antioxidant activity and phenolic content of Oregon caneberries. J. Agric. Food Chem. 2002, 50, 3495-3500. [CrossRef] [PubMed]

85. Iino, T.; Nakahara, K.; Miki, W.; Kiso, Y.; Ogawa, Y.; Kato, S.; Takeuchi, K. Less damaging effect of whisky in rat stomachs in comparison with pure ethanol. Role of ellagic acid, the nonalcoholic component. Digestion 2001, 64, 214-221. [CrossRef] [PubMed]

86. Ayhanci, A.; Cengiz, M.; Mehtap Kutlu, H.; Vejselova, D. Protective effects of ellagic acid in D-galactosamine-induced kidney damage in rats. Cytotechnology 2016, 68, 1763-1770. [CrossRef] [PubMed]

87. Iino, T.; Tashima, K.; Umeda, M.; Ogawa, Y.; Takeeda, M.; Takata, K.; Takeuchi, K. Effect of ellagic acid on gastric damage induced in ischemic rat stomachs following ammonia or reperfusion. Life Sci. 2002, 70, 1139-1150. [CrossRef]

88. Lei, F.; Xing, D.M.; Xiang, L.; Zhao, Y.N.; Wang, W.; Zhang, L.J.; Du, L.J. Pharmacokinetic study of ellagic acid in rat after oral administration of pomegranate leaf extract. J. Chromatogr. B Anal. Technol. Biomed. Life Sci. 2003, 796, 189-194. [CrossRef]

89. Priyadarsini, K.I.; Khopde, S.M.; Kumar, S.S.; Mohan, H. Free radical studies of ellagic acid, a natural phenolic antioxidant. J. Agric. Food Chem. 2002, 50, 2200-2206. [CrossRef]

(C) 2019 by the authors. Licensee MDPI, Basel, Switzerland. This article is an open access article distributed under the terms and conditions of the Creative Commons Attribution (CC BY) license (http://creativecommons.org/licenses/by/4.0/). 